2016-03-18

Baghdad's thirdspace: Between

liminality, anti-structures and territorial mappings

\title{
Murrani, Sana
}

http://hdl.handle.net/10026.1/4388

\subsection{7/0921374016634378}

Cultural Dynamics

Sage

All content in PEARL is protected by copyright law. Author manuscripts are made available in accordance with publisher policies. Please cite only the published version using the details provided on the item record or document. In the absence of an open licence (e.g. Creative Commons), permissions for further reuse of content should be sought from the publisher or author. 


\title{
Baghdad's thirdspace: Between liminality, anti-structures and territorial mappings
}

\section{Sana Murrani}

Plymouth University, UK

\begin{abstract}
Wedged in-between the dense urban grain of Baghdad, blast walls of $t$-shaped concrete have littered the streets and neighbourhoods since 2003, after the US led invasion. The idiosyncrasy of these walls lies in their exaggerated spatial liminality. They appear, change location and disappear overnight, and on a daily basis, leaving Iraqis to navigate through labyrinths of in-between spaces. This article critically reveals the new social and power structures that have emerged in the context of the city in response to the condition resulting from this unique urban intervention. This uncanny spatial and social condition of permanent liminality will be analysed through Victor Turner's critical theories of liminality and anti-structure coupled with Edward Soja's theory of Thirdspace, interpreting, through a series of territorial mappings, a complex liminal condition in a contested and disrupted city.
\end{abstract}

\section{Keywords}

anti-structures, Baghdad, critical urban theory, liminality, thirdspace

\section{Introduction: Baghdad, 2016}

Iraq and, in particular Baghdad, has become a battleground with consequences entrenched in the everyday lives of Iraqis. State power structures and social structures have fallen further out of sync ${ }^{1}$ with one another (Al-Ali, 2014: 103). Socio-cultural factors as well as the vacuum of order created by the invading troops and the disbanding of the Iraqi army have shaped the ethno-sectarian conflict after 2003 and contributed to the rise of new powers in the form of 'sub-state sectarian political identities' (Dodge, 2014: 6). Recently, Iraq as a whole has seen a new power structure, a jihadist group based on terror, brutality and intimidation, in the name of ISIL/ISIS (Islamic State in Iraq and the

\section{Corresponding author:}

Sana Murrani, School of Architecture, Plymouth University, 204 Roland Levinsky Building, Plymouth PL4 8AA, UK.

Email: sana.murrani@gmail.com 
Levant, currently called Islamic State (IS)). In June 2014, IS took advantage of cracks and weaknesses in the Iraqi government, then led by Nouri Al-Maliki, especially in Sunni stronghold areas, and has gradually begun to make incursions towards Baghdad (Lewis, 2014). As a result, Baghdad has witnessed an increase in civilians joining the Iraqi army, ${ }^{2}$ and the resurfacing of militias such as Muqtada ${ }^{3}$ Al-Sadr's followers (Dobbins et al., 2009: 321).

It is the intention of this article to emphasise the perception long ingrained in Iraqis' minds of the systematic denial of basic civil rights by the state (Al-Ali, 2014: 22), which over years of accumulated neglect and oppression has contributed to the clear division between power structures (state power and other imposed external and internal influences) and social structures (the cultural relationships between ordinary Iraqis). However, it is naive to think that the divide between the formation of new power structures and the emergence of new social structures is binary and polarised. Power and social structures have exchanged roles and in doing so have generated a complex and multi-layered map for the city of Baghdad, which I will explore through the concepts of Victor Turner's anti-structures and Edward Soja's thirdspace to reveal how Iraqis experience the locatedness of these structures within the urban context of the city.

Baghdad has had an eventful history since Caliph Al-Mansur first announced it as the capital of the Abbasid ${ }^{4}$ Caliphate in the year 762 AD. The Abbasid Caliphate's circular walled $^{5}$ and gated fortification of the city with its centralised head of state and power, has defined the city's main characteristics and sense of locatedness (Peterson, 2002). Despite this fortification, Baghdad has been subjected to numerous sieges, battles and wars. Its history of violence began with the invasion of the Mongols led by Hulagu Khan in 1258, followed by the Turks in 1638 (when the Ottomans wrested Baghdad from the Persian Empire) and 1920 saw the British colonisation (following an invasion in 1917), which was part of the British Mandate after the First World War. This was followed by three coup d'états after the official announcement of Iraq's independence in 1932. The first, in 1958 overthrew the monarchy in favour of the first republic; the second, in 1963 brought with it a taste of a violent military republic and on the third occasion in 1968 the Socialist Arab Ba'ath party took power in Baghdad (NGO Coordination Committee for Iraq, 2010).

In 1979, Saddam Hussein become president of Iraq, followed immediately by an 8-year war between Iraq and Iran (1980-1988), and later by Iraq's invasion of Kuwait in 1990 and the First Gulf War in 1991, after which the UN Security Council Resolution $661^{6}$ imposed sanctions that lasted nearly 13 years in which Iraq and particularly Baghdad fell into complete despair. However, it was not until the 2003 US led invasion of Iraq that Baghdad regressed to a state worse than that caused by the Mongolian invasion back in 1258. Shock and Awe's massive bombardment lit and rocked Baghdad at the dawn of a tremendous war that began on 20 March of that year targeting infrastructure, military and industrial bases. Three weeks later, Baghdad fell to the control of the US-led Multinational Forces in Iraq (MNF-I), forcefully symbolised by the famous toppling of Saddam Hussein's statue in Baghdad's Firdos Square on 9 April (Anderson, 2004).

This historic account brings us to the very beginning of the period of interest for my article, a period marked by the formation of the US-led Coalition Provisional Authority (CPA), announced by the UN Security Council ${ }^{7}$ as the official occupier on 22 May 2003. The CPA came to fill the vacuum of power created by the dissolution and disarming of 
the Iraqi police and the Iraqi military immediately after the fall of the regime (NGO Coordination Committee for Iraq, 2010). This action triggered escalating violence, leading to the deterioration of security in Iraq, encouraging further looting, kidnapping and the emergence of insurgencies (Al-Ali, 2014). Meanwhile, the US walled off a $3.5 \mathrm{sq}$. mile (nearly 10 sq. $\mathrm{km}$ ) area in central Baghdad that formed the main insulated base of power for the CPA, the Green Zone. ${ }^{8}$

A surge in the so-called temporary use of concrete walls that began to litter Baghdad's urban context demarcated further conflict amongst Iraqis both socially and culturally. Since then Iraqis have had to contend with the contingency of life on the fringes of blast walls, ${ }^{9}$ barbed wire, and checkpoints that have changed and continue to subvert the urban grain of the city and disturb its social context. My intention, here, is to reveal the ways in which social and anti-structures are emerging and adapting to the constant shift and the liminal existence of walls in the city of Baghdad, a subject that has received little discussion considering the colossal impact that these walls have had on communities and existing social structures (Damluji, 2010).

\section{Territorial liminality: Power, communitas and anti-structures in thirdspace}

Studies of walls in conflict zones are not unprecedented. Here, I have particularly focused on research carried out on the spatial and social impact of walls in conflict zones. There are studies of the wall between Israel and Palestine (Ibhais and Ayed, 2013; Pullan, 2013; Weizman, 2007), the Berlin wall and the Belfast Peace wall (Boulton, 2014). Despite having differing objectives, these walls provide a rich context and all share a defined function - to create an impenetrable divide between two territories in a time of conflict. ${ }^{10}$ The walls in Baghdad, in contrast, are discontinuous: Fragments of walls are scattered across the city surrounding individual neighbourhoods, civic buildings, and military compounds. They dissect the city into a maze of urban agglomerations as opposed to defining a clear division into two regions.

Previous literature on the subject of Baghdad's blast walls has covered the impact of these urban structures on the segregation between Sunni and Shiite neighbourhoods in the city (Damluji, 2010: 72); the new emerging urban morphology and forms within the city between private and public spaces (Al-Hasani, 2012: 89), and the potential social impact of beautifying these walls with murals (Pieri, 2014). In a manner similar to how Adrian Lahoud (2010) situates conflict at the heart of how cities are shaped, I view the conflict resulting from the walling strategy in Baghdad as a catalyst for the emergence of new power and social structures and propose to contribute to this literature with a critical analysis of the way in which these walls have catalysed the generation of new social and power structures in the city by altering the urban context. This examination of Baghdad's urban and social context evinces the ways in which long-term conflict can assist in generating creative social and cultural dynamics that help people navigate their city.

The liminal condition of the existence of Baghdad's walls (existing and changing location overnight and on a daily basis), coupled with the complex layering of the social and power structures emerging as a result of the walling strategy, are unprecedented. The changing locations and sizes of these walls are quintessentially strategic and tactical, 
operating within the slips and gaps of the social and spatial patterns of the everyday life of the city. Wedged in-between communities, such walls have broken the network of social orders - or perhaps layers of degrees of orders that existed within the city prior to the 2003 war - but they have also instigated conditions and agglomerations within the city that are original and territorial, both spatially and socially. The walling strategy did not only contribute to dividing the city geographically, it also allowed new pockets of social structures with different territorial and political beliefs to emerge. Baghdad emerged not merely as a city divided into two distinct sides (green and red zones) but instead as a complex metropolis with mesh-like layers of external interests and internal territorial ${ }^{11}$ structures, social structures, and anti-structures changing location on a daily basis. I consider the territories of power and social structures that are emerging on the cusp of the blast walls in Baghdad to be an integral part of the analysis of the city's current situation.

Iraqis, particularly Baghdadis, have for generations been born in poorly equipped hospitals in a city under constant bombardment. For them, being in conflict has become a rite of passage. Moreover, the existence of the walls has added another layer of tension to this conflict. The uncertainty in everyday life is no longer threatened only from above but also from across the walls and in-between the urban context, manifesting itself in sectarian violence and civil war. This uncanny spatial and social condition of permanent liminality (Thomassen, 2009) is enunciated and interpreted through anthropological theories of the 'rites of passage' by Arnold van Gennep and in particular the middle stage:12 'margin' or 'limen', which is later developed by British anthropologist Victor Turner to be the 'liminal period' of 'betwixt and between'. Turner (1964) was referring to the anthropological connotations of the term 'liminal' in a social and societal context to mean 'in between states of being' (Turner, 1964). Turner (1974) believes that liminality holds both positive and negative qualities, "especially where that "threshold" is protracted and becomes a "tunnel" when the "liminal" becomes the "cunicular" (p. 72). I intend to extend the use of social inter-structures of the liminal state to attribute social creativity and adaptability to blast walls, barbed wire and checkpoints, where individuals inhabiting distinct social contexts on either side of the divide maintain parallel everyday lives which are profoundly out of sync with the centres of power and government (both inside and outside the Green Zone).

However, before delving into the details of Baghdad's emerging power and social structures, we need to further define a few terms that will feature in the critical analysis of the impending discussion. Liminality, that is, all that is marginal, ephemeral and on the periphery, is a social and a spatial condition that implies a temporal dimension akin to the becoming of transitional events and situations that are situated neither here nor there, rather in-between. This spatial and temporal condition and locatedness of liminality is closely related to postmodern studies of thirdspace (a term coined by Edward Soja, 1996) in that they both reject a binary logic of either/or and instead offer an open alternative continually building on approximations of knowledge. However, while liminality explains social conditions of being in the world, thirdspace provides alternative readings of spatial otherness and becoming in the world.

For Soja (1996), the 'third' in thirdspace refers to spatial 'otherness', beyond what is lived and what is conceived, real and imagined (referring to Henri Lefebvre's conceptual 
triad between spatial practice, representation of space and spaces of representation) (Lefebvre, 1991). 'Third-as-Other' is an open spatial and social system with an expansion beyond 'permanent constructions' (Soja, 1996: 61). Soja (1996) asserts that this critique of space is not meant to stop at three, but rather for 'thirding-as-Othering' to be: '[...] designed to break down and disorder a rigid dichotomy and create a Thirdspace, an alternative "postmodern geography" of political choice and radical openness attuned to making practical sense of the contemporary world' (p. 63).

Soja's notions of 'thirding' and 'thirdspace' can be seen as a combination of being and becoming, ontologically and epistemologically related to the constructs of the liminal states of Baghdad's power and social structures. The perpetual complexity resulting from the invasion of Iraq by Western powers aided the emergence of the pure liminal condition from which Iraq now suffers. The current situation in Iraq, as a whole subsequent to the formation and expansion of Islamic State, is no longer defined by the biopolitics ${ }^{13}$ (Foucault, 1997) of Western powers - where society and politics possess power over life - but rather by the necropolitics ${ }^{14}$ (Mbembe, 2003) of an unstable war state. Marina Gržinić (2012), a contemporary philosopher and an expert on theories of ideology, technology and biopolitics/necropolitics, offers a definition of 'war state' which could be used to describe the current Iraqi government led by PM Haider Al-Abadi, where 'the state apparatus exists only to maintain the illusion of social harmony, not to take care of the lives and needs of a proper population' (Gržinić, 2012).

There exist different degrees of liminal experience depending on the spatial and temporal condition being affected. For the last 12 years, Baghdad has been subjected to urban segregation and extreme structural marginalisation of its spatial and social context. Its citizens are now fully embedded in what Thomassen (2009) calls a pure liminal state, where the effects of social change have not only impacted social relations but have also extended to reach temporal space (Thomassen, 2009). The state of the emplacement of Baghdad's walls is a heterotopia (borrowing Foucault's term to mean spaces of otherness) in which the 'displacement of time is matched by the disruption of space' (Johnson, 2006).

Turning to ritual processes and anthropological theory might seem at odds with my subject matter. However, I suggest a hypothesis that is derived directly from anthropological theory concerning the interpretation of rituals in cultures. Rituals are universal components of culture, yet this universality yields a multiplicity of social practices that are inherent within human experiences, which, in turn, can be applied to interpret urban contexts within a universal conceptual framework. I propose that people who exist in contexts with power and social structures that suffer from embeddedness of permanent conflict will be accustomed to that conflict in their everyday lives. Therefore, conflict becomes a rite of passage and part of everyday rituals.

Turner (1974) states that symbols in any culture are identified in ritual processes as events and situations rather than things in time. He further denotes that 'Symbols, [...], are crucially involved in situations of societal change' (Turner, 1974: 54). Now if we agree to consider the blast walls as an urban and spatial symbol, then we can begin to construct an argument whereby the walls act to generate new power and social structures or anti-structures. Turner (1974) uses the term anti-structure to denote any social condition that exists outside social status, social hierarchy or any pervasive social category such as class, sex or age-division. Anti-structures emerge in liminal periods, examples of 
which are conflicts, wars and famines. The emergence of anti-structures when families in Baghdad open their houses to displaced families or individuals due to the sectarian violence between Sunnis and Shiites is an example of what Turner terms 'spontaneous communitas', a product of anti-structure. However, anti-structure is not meant to be understood as a 'structural reversal, a mirror-imaging of 'profane' workaday socioeconomic structure, or a fantasy-rejection of structural 'necessities'. but the liberation of human capabilities of cognition, affect, volition, creativity, etc' (Turner, 1974: 75). Liminality is a product of anti-structure and so is communitas. Anti-structure relates to open-systems, whereas communitas constitute a product within such systems, Turner (1974) explains,

[...] communitas preserves individual distinctiveness - it is neither regression to infancy, nor is it emotional, nor is it 'merging' abstract processes generalized and segmentalized into roles, status, classes, [...], and so on. In different types of social situations they have been conditioned to play specific social roles. It does not matter how well or badly, as long as they 'make-like' they are obedient to the norm-sets that control different compartments of the complex model known as the 'social structure'. (p. 77)

Liminality and communitas, when compared to the structural norm, share the characteristics of being both more creative and more destructive. However, neither liminality nor communitas represent the elimination of structural norms from the consciousness of the participants, but rather, they depend on the symbolic cultural structures in which the participants are involved. Turner (1974) refers to this readiness to convert into normative structure as a 'vulnerability to the structural environment' of liminality and communitas (p. 78).

It seems that there is a clear convergence between the conceptual frameworks of Turner's anti-structure and Soja's thirdspace, in that both are open systems where the former acts as a seedbed for societal change and the latter acts as a node for the emergence of spatial otherness in any urban context. This critical social and spatial thinking will demarcate the principles according to which I will map Baghdad's power structures and societal anti-structures. Given the shifting geographies of Baghdad, the maps presented here are vehicles of exploration and conceptual constructs rather than depictions of physical reality. In an environment where social structures are in a constant territorial battle with power structures, and the geopolitical and the biosocial are in a pure liminal state, maps in their conventional sense fail to truly capture this complex context.

\section{Mappings of territories: Social and spatial structures and anti-structures}

Maps and territories conjointly are representations of complex structures (whether power or social constructs). Eyal Weizman (2003) asserts that an alternative method of constructing maps should include not only the spatial two-dimensionality of a place but rather its multi-dimensionality of social, political and cultural formations. He states, 
Territories are governed by the production and dissemination of knowledge as much as they are governed by military force. Maps have always been principal tools in the understanding and governing of territories. The history of their making relates to the marking of property ownership, political sovereignty, and power. (Weizman, 2003: 65)

Rob Kitchin and Martin Dodge (2007) extend Weizman's proposition to the ephemerality and the liminality of the meaning and the process of making maps. Kitchin and Dodge (2007) assert,

[...] maps are of-the-moment, brought into being through practices (embodied, social, technical), always remade every time they are engaged with; mapping is a process of constant reterritorialization. As such, maps are transitory, and fleeting, being contingent, relational and context-dependent; they are always mappings. (p. 1)

Adopting Kitchin, Dodge and Weizman's positions on maps and mappings, I will embark on a series of five territorial mappings that begins with an exploration of the relationship between the power and social structures of the city of Baghdad during Saddam Hussein's regime in relation to the original footprint of Baghdad going back to the Abbasid era. This first territorial mapping will highlight the localisation and centralisation of power structures within the urban context of the city, and it further highlights the extent of the fortification of such structures when compared to the organic urban grain of the city's social structures. The second territorial mapping emphasises the shift in the locatedness of the power structures at the onset of the 2003 invasion of Baghdad and the formation of the centralised Green Zone area in relation to the disturbance of the rest of the city (known as the Red Zone). The third territorial mapping attempts to reveal the anti-structures initiated alongside the widespread appearance of blast walls in the city. This stage of the territorial mapping will be accompanied by five key photographs, ${ }^{15}$ taken by award-winning photographer Kai Wiedenhöfer, of the emerging social nodes and anti-structures in and around blast walls and checkpoints across the city. The fourth territorial mapping reveals the extent of the sheer number of pockets of insurgencies and the emergence of new power structures and anti-structures in the form of religious militias, Al-Qaeda, militants, and so on as compared to the displacement of social structures. At this stage, power structures are no longer centralised but rather appear in an expanded network that stretches outside the country to foreign lands that control or influence what goes on in Iraq. The fifth territorial mapping defines a much more ambiguous territory. It reveals the impact that social nodes and networks, such as social media and journalism have on social structures in the city.

In the previous section, I proposed that Baghdad in its current state, a state of conflict, has reached a pure liminal state, an open system, where new social communitas and antistructures embedded in thirdspace are likely to emerge. This pure liminal state evokes Adrian Lahoud's (2010) consideration of crisis as a productive process within the newness distilled via trauma in what he calls 'post-traumatic urbanism', he continues, 'Trauma forms an epistemological blind spot, a limit space behind which known experience recedes. This is why there is another name for trauma: 'the new'. In some sense the traumatic event is excessively new' (p. 19). 
Therefore, the territorial mappings that will follow are manifestations of a continuous process of new mapping, territorialisation and structuring, rather than end products in themselves. They attempt to cover the most prominent situations. They are not inclusive of every event that has taken place over the last decade or so, but rather they collate and overlay the most dominant and elemental in relation to societal and spatial change in the city.

\section{Territorial mapping | I: Centralised power structures until 2003}

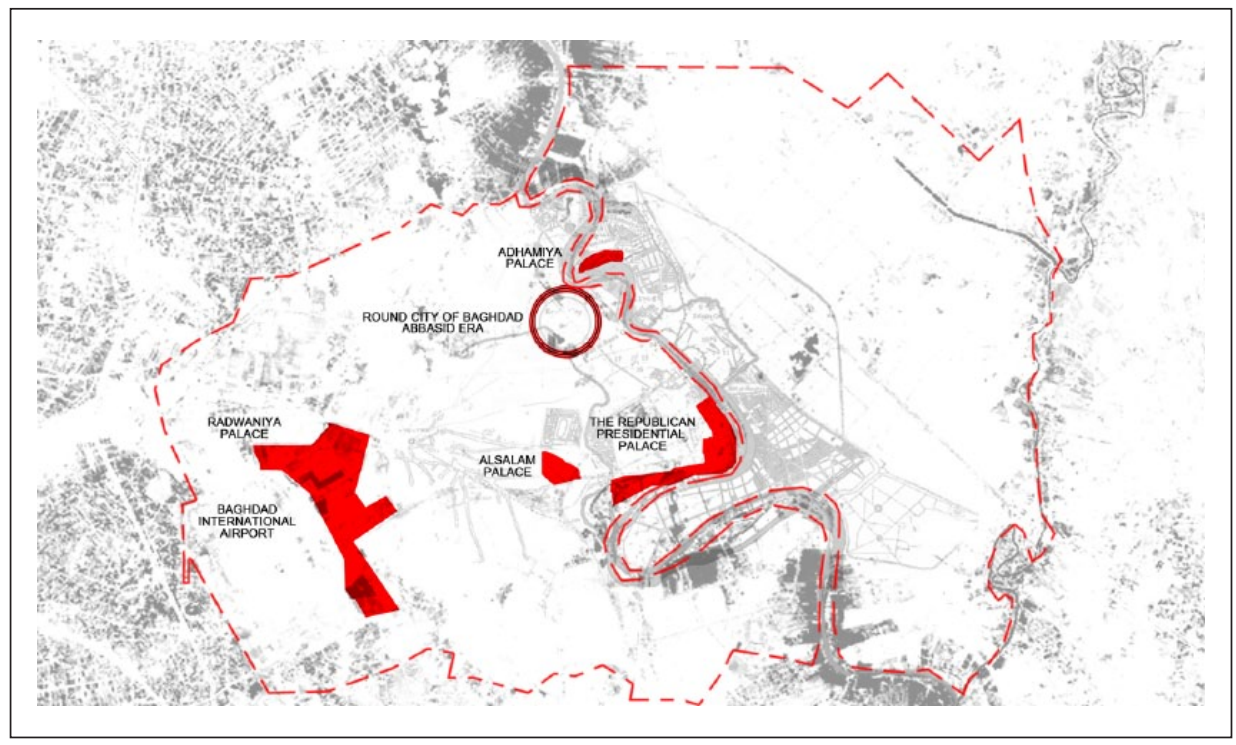

Figure I. Centralised power structures.

This territorial mapping (Figure 1) shows the expansion of the urban context from the circular walled historic city to the pre-2003 era and the distribution of centralised power structures (palaces and the airport). In Baghdad, during the Abbasid era (13th century), there was a readily apparent relationship between state and social structures. The city was designed with a clear intention to separate power and social structures. Its head of state, the mosque and palaces occupied the majority of the central context of the city while the first of its three circular walls separated this private centre from public housing. Its radiating design, which is supported by four main symmetrical gates, maintained its circular structure until the end of the 19th century. Due to its original limited capacity and an increase in population, growth and development in Baghdad's urban context radiated outside its walls and to the east of the river Tigris (Al-Hasani, 2012).

This lucid binary urban structure remained more or less the same during Saddam Hussein's regime. The regime had a centralised strategy which required the state structures (palaces, ministries, governmental buildings, etc.) to be literally located centrally 
within the city while maintaining strategic sites within other neighbourhoods in the city to be used as 'human shields', ${ }^{16}$ as well as arms and military equipment caches during wartime (primary schools, public bomb shelters and mosques) to weaken social structures. Despite the regime's efforts to embed ethno-sectarian differences through intimidating and discriminatory practices, in general, people in Baghdad lived together in mixed social heterogeneous communities consisting of Sunnis and Shiites as well as other ethnic minorities (Damluji, 2010: 73). Radical ideologies and extremism were not yet embedded in the social structure of the city.

At that time, Iraqis were ruled by a regime that embraced the Arab Ba'ath Socialist Party's agenda and ideology (originated in Syria in the '40s) to free the Arab world from colonialism. The party's power structure at that time adhered to their slogan, 'Unity, Liberty, and Socialism' only in a very narrow sense. Unity, for the party, meant a unified Arab nation regardless of cultural differences, while liberty only concerned liberating the nation from foreign intruders rather than promoting a democratic way of life, and socialism only meant cooperation between Arabs as one nation against imperialism and the West (Salem, 1994). Iraqis faced a choice between joining the party or being exiled or executed. This ideology left no room for thirding-as-othering to exist. The relationships depicted by Soja's concept of thirdspace would have been brutally destroyed.

\section{Territorial mapping | 2: Formation of the Green Zone and disturbance of the Red Zones}

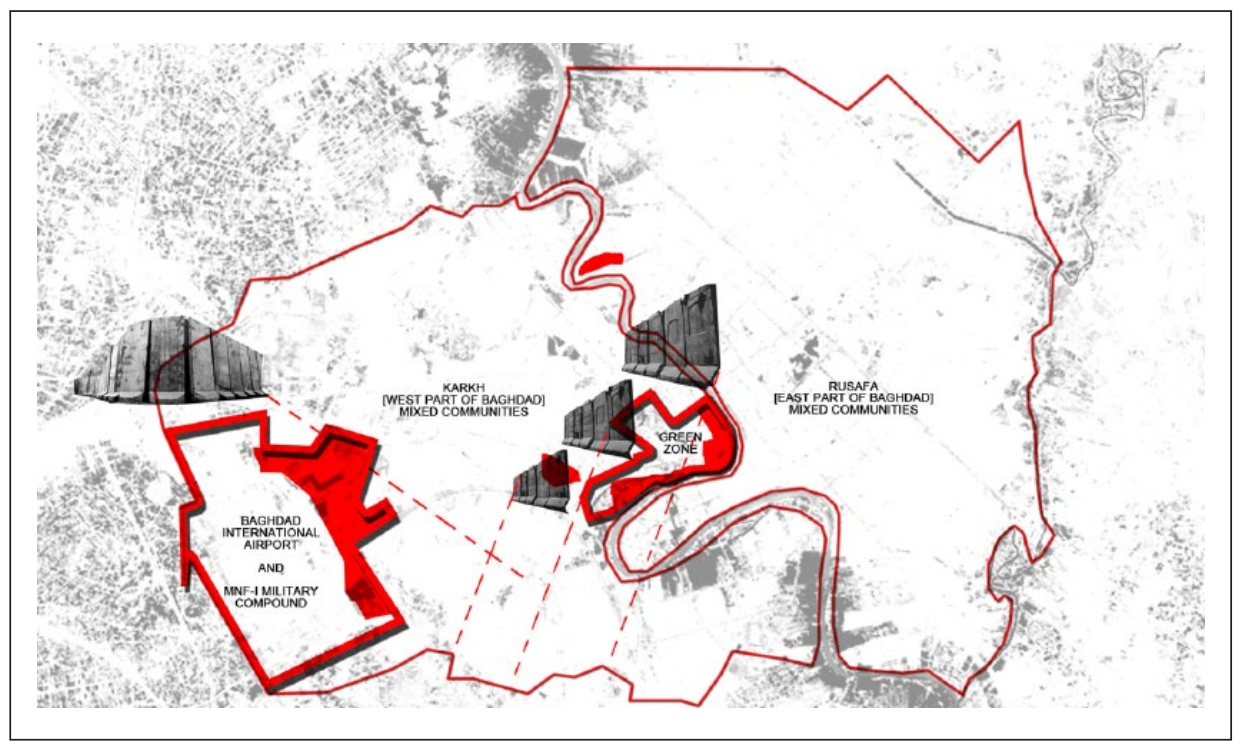

Figure 2. Fortified areas (Green Zone and airport) vs Red Zone (rest of Baghdad).

The fortified centralised power establishment that urban dissection imposed in the early days of the formation of Baghdad as a capital for the Abbasids, continuing through the 
Ba'ath Socialist Party Regime led by Saddam Hussein, has been maintained with the CPA headquarters (Green Zone) and consequently with the current Iraqi government and the international presence in the city (Figure 2). The Green Zone area occupied most of the southern half of the Karkh District situated in West-central Baghdad, which ironically was originally home to a number of Saddam Hussein's palaces, government ministry buildings and the residences of government officials (Houghton and McDonald, 2006). Contrary to the widespread misunderstanding as to how much of the so-called Green Zone was accessible to Iraqis before 2003, the current International Zone is far larger, more isolated and more disconnected from the rest of the city spatially and socially than the previous regime's centre of power (see Figures 1 and 2 for comparison).

In her essay on Disaster Capitalism, Naomi Klein (2007) described the Green Zone as an enclave, a by-product of the war, 'like a giant fortified Carnival Cruise ship parked in the middle of a sea of violence and despair, the boiling Red Zone that is Iraq' (p. 48). Unlike the rest of the city of Baghdad (the Red Zone), the Green Zone is provided with its own electrical and communication grids in addition to sanitation systems, oil supply, and a fully operating hospital, all inside a 5-m-thick wall that fences it in (Klein, 2007). On the cusp of this period, Baghdad witnessed a defined binary power structure (Green Zone vs. Red Zone) unlike any seen before. Social structures suffered an equally if not more strongly delineated division between people who were paralysed by overwhelming fear and others who out of sheer audacity continued to operate within the city.

\section{Territorial mapping | 3: Communitas, anti-structures and blast walls}

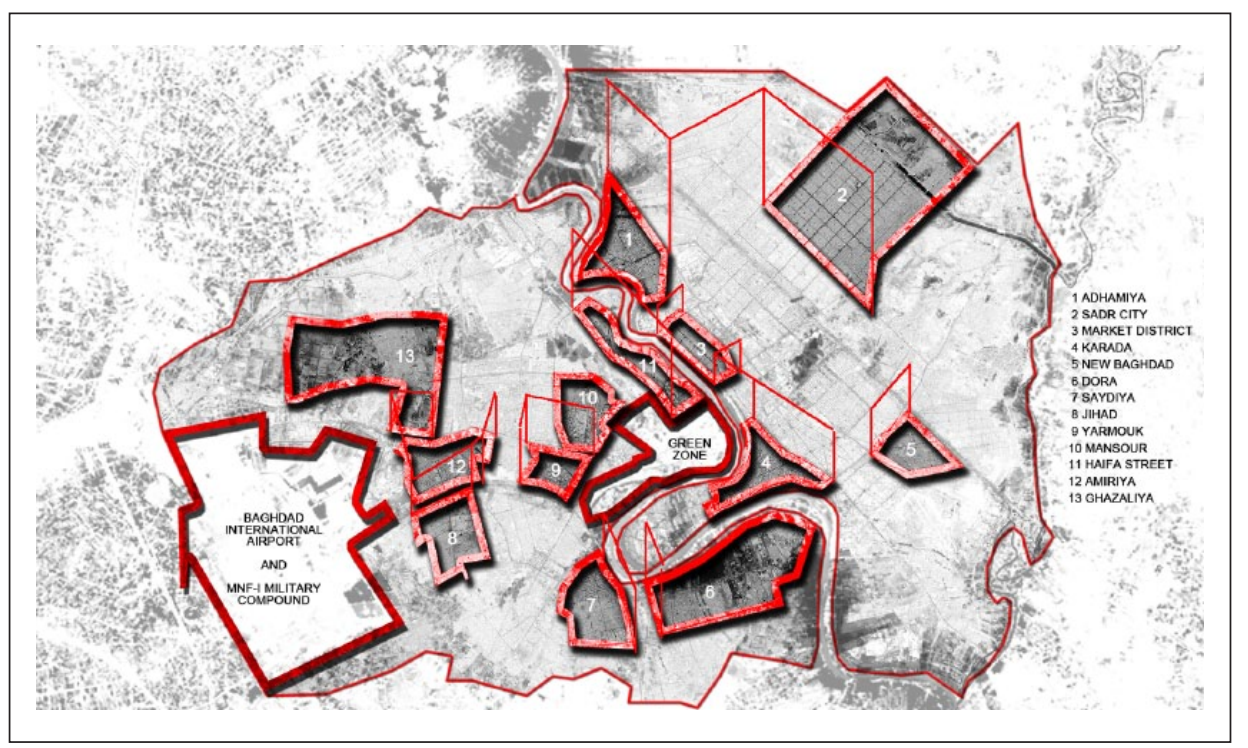

Figure 3. Walling strategy.

Following the walling of the Green Zone, the deployment of concrete walls, lodged in every neighbourhood in Baghdad, became a marked feature of the urban landscape 


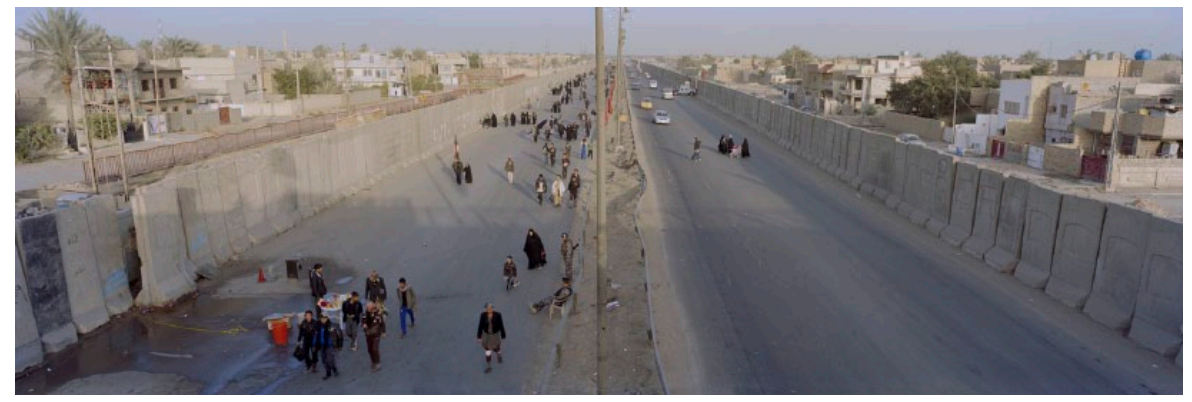

Figure 4. Dora Expressway, Baghdad 2012 (courtesy of Kai Wiedenhöfer).

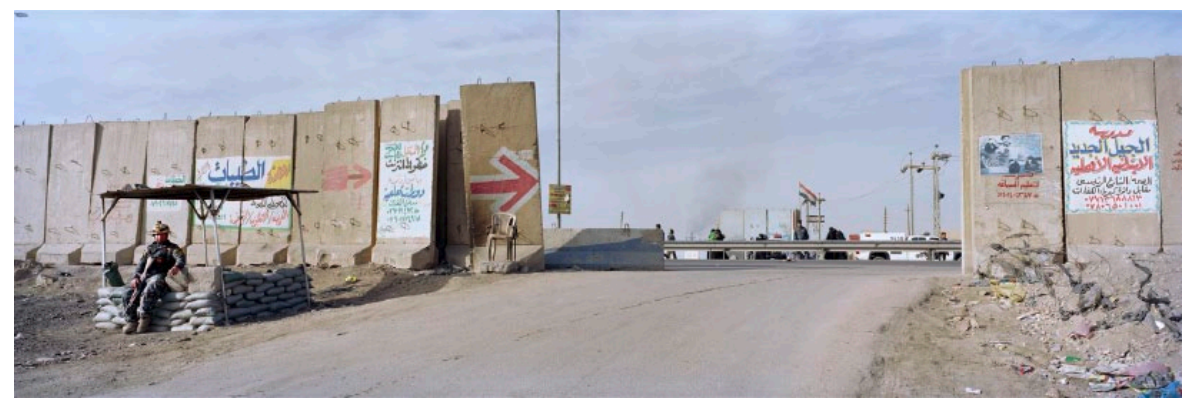

Figure 5. Saidiya, Baghdad 2012 (courtesy of Kai Wiedenhöfer).

(Figure 3). The first of these walls was 3 miles long $(5 \mathrm{~km}), 12$ feet high $(3.6 \mathrm{~m})$ and constructed from T-concrete blast wall segments. The wall was instigated to separate the Adhamiya area, a predominantly Sunni neighbourhood, from the surrounding Shiite neighbourhoods amid the wave of ethnic cleansing that occurred in 2006.

Blast walls come in different sizes, shapes and heights. In the years following 2007, their construction was a lucrative multi-million dollar business with factories in the North of Iraq (mainly in Gopala, northeast of Kirkuk, a region of Kurdistan) (Farrell, 2008). Contracted by the MNF-I (Multi-National Forces in Iraq), Kurdistan produced the blocks while US contractors such as Halliburton erected the walls under the protection of mercenary companies such as Blackwater. Due to the serious level of danger associated with putting up these walls, barriers and checkpoints - in the form of insurgent operations targeting US-led and government interventions in the city - they were all erected overnight. As a consequence, Baghdadis awoke each day to a newly reconfigured and torn spatial labyrinth (Figure 4), a city that they once traversed freely, with new walls and new checkpoints materialising in the urban context daily (Figure 5). Walls were no longer used only in dangerous neighbourhoods but also extended to encompass hotels, universities, embassies and hospitals in addition to ministry buildings, mosques and markets.

The spatial existence of the walls and their effects on the social context has been discussed before (Damluji, 2010; Gregory, 2008; Klein, 2007). My intention here is to expose the ways in which social structures have emerged to respond to this ephemeral 


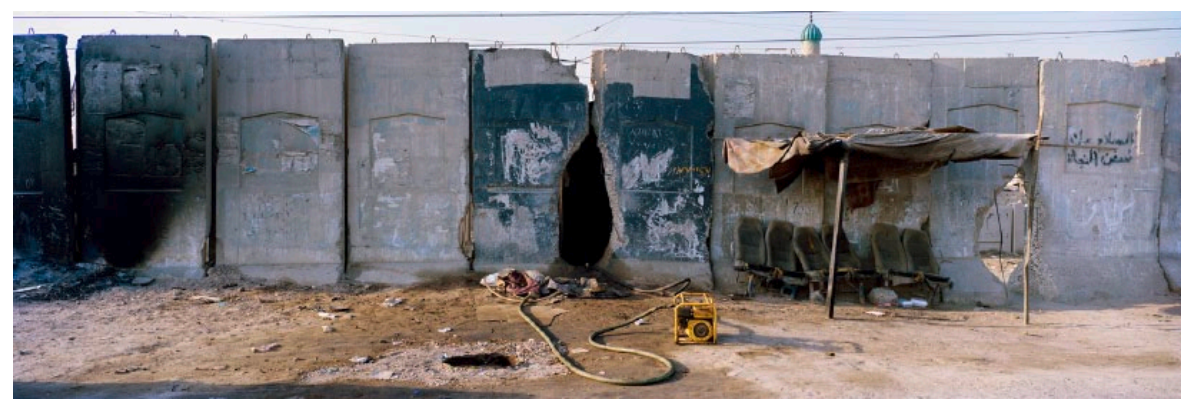

Figure 6. Sadr City, Baghdad 2012 (courtesy of Kai Wiedenhöfer).

transformation in the spatial configuration of the city and to expose how that clear binary division between the Green and Red zones began to breakdown. Nonetheless, it is important to note the MNF-I's intention for the walling strategy and gated community style enclaves. This was to stop sectarian violence in three ways (Figure 6): by making it difficult for terrorists to operate attacks from within that neighbourhood (due to checkpoints preventing the smuggling of bombs or arms), by supporting the implementation of security controls to help protect the gated communities against insurgency and by empowering communities against retaliation (Kilcullen, 2007).

In 2007, communitas and anti-structures surfaced from under a wave of un-organised crimes, looting and kidnapping, which soon after developed into power structures in the form of Sunni insurgency and Shiite militias who assumed people's religious affiliation from their names (Figure 7). Iraqis resorted to carrying two different ID cards bearing different names - one fake and one original - to use as they attempted to navigate the city. As described by Damluji (2010), these ID cards formed the very first product of antistructures in the city. 'Not only fake IDs, but also name changes, false license plates, religious bumper stickers, and mobile ringtones served as sectarian markers, which men could use to manipulate sectarian identity and increase mobility in the segregated city' (Damluji, 2010: 79).

In 2008, another manifestation of communitas came in the form of a drive to beautify the grey-wall-littered landscape of the city by commissioning artists to paint murals on the walls. Despite the enthusiasm expressed by the Walls Group (also known as Jama'at Al-Jidar), a group of artists who believed in the call to beautify Baghdad, a few Baghdadi artists have expressed their concern as to the lack of freedom of expression as all murals were a result of precise decision-making between the MNF-I (the commissioners) and the artists. Even though they were free of any religious connotations and only alluded to cultural references, they were not a spontaneous expression of feelings. Caecilia Pieri (2014), who has conducted research on these murals, says of them:

They dramatize an urban space which becomes the backdrop for a staged fantasized common past, a set advocating a fragile Iraqi unity, constantly challenged by the political incapacity and/ or reluctance to rule the capital as a unified entity. In that sense, the murals can be said to be the visual expression of a double discourse (national unity in words versus antagonistic reality in facts), which is a recurrent topos in Iraqi politics. (Pieri, 2014) 


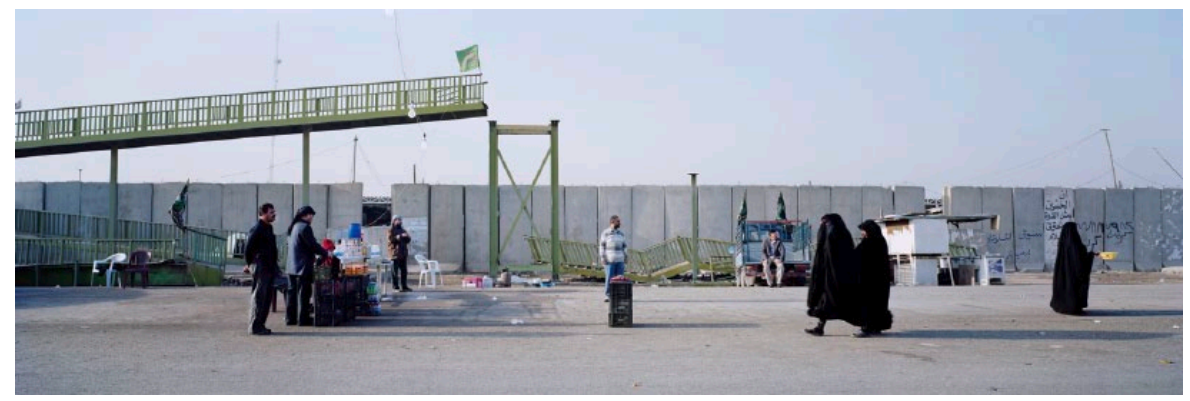

Figure 7. Omar Khattab Street, Baghdad 2012 (courtesy of Kai Wiedenhöfer).

Pieri seems to describe the death of the idea of communitas in Baghdad's mural artists. Through the direct influence of power structures (MNF-I commissioners in this case), the very basic notion of anti-structure has been pulled towards the structural norm. However, Turner reminds us that this is the fragility of the construct of communitas. These walls are not permanent, they are moved about overnight and when some come down they end up in one of the graveyards that are scattered on the outskirts of Baghdad (Finoki, 2009). This characteristic of the walls defines the condition of liminality in this context.

Other analysts address the morphing complexity of urban Baghdad. They have highlighted the fact that in some cases the blast walls have brought back genius loci (meaning, spirit of place) ${ }^{17}$ to some places by dissecting the old parts of Baghdad and recreating pedestrianised areas and no car zones around famous old and traditional markets such as Al-Rasheed Street and Al-Mutanabbi Street (Al-Hasani, 2012: 83). These markets have since become flooded with visitors who feel relatively safe to enter and browse. Perhaps this strategy was not intentional but rather a product of the chaotic and sporadic decision-making process of the walling strategy. Nonetheless, small pockets of communitas are becoming more and more prominent. It is interesting to note Turner's belief that when products of communitas are smaller and less structured they are better able to sustain their existence than when they are widespread and conform more strongly to structural norms (Turner, 1974: 82-83). Therefore, we should not expect the communitas found in the old markets to be replicated across all markets in the city. In segregated neighbourhoods, markets have emerged and become sustained in the shadow of the blast walls. Given that the summer heat in Baghdad can reach $45 \mathrm{C}$, any ad hoc shade could provide a space for a vegetable stall (Figure 8).

Other examples of communitas came in the form of arrangements to sustain work. Taxi drivers exchange passengers and truck drivers swap cargo 'for destinations that lie across the fault lines' between two districts that maintain allegiances to two different sectarian groups (Gregory, 2008: 37). 'Turf wars' have changed the face of Baghdad as it becomes more segregated and divided, and have become the main contributor to the mass displacement of Iraqis since the war started (Gregory, 2008: 37). 


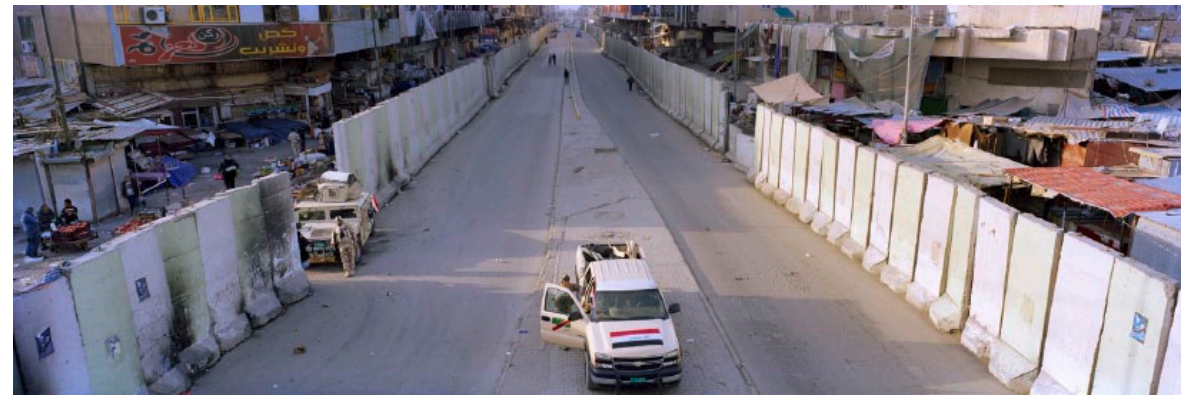

Figure 8. Shorja Market, Baghdad 2012 (courtesy of Kai Wiedenhöfer).

\section{Territorial mapping | 4: Explosion of new power structures and displacement of social structures}

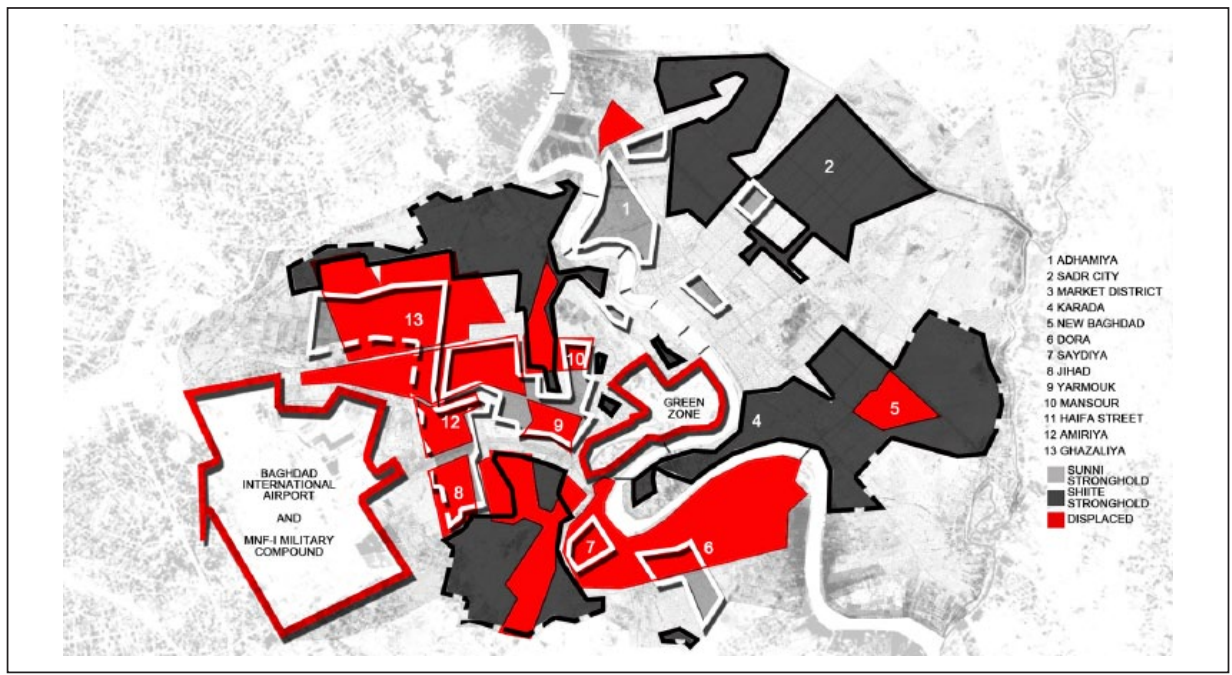

Figure 9. Segregated urbanism between Sunni and Shiite strongholds.

The power structures of Baghdad have morphed and warped on several occasions in the last decade. Breakdown in the simple but highly dictatorial and singular power structure imposed during the Saddam Hussein's era has had an impact on the existing social structures and allowed new power structures to emerge in the city following the fall of the regime. A multitude of new powers emerged gradually taking advantage of the power vacuum first created by the bombardment in 2003 and followed immediately by the CPA's (US led CPA) call for the de-Ba'athification and disbanding of the Iraqi army which led to the creation of high levels of unemployment and a sense of resentment towards the occupation. Without a clear post-war plan by the MNF-I, lootings, kidnappings and organised gangs began to appear, which encouraged a walling 
strategy that resulted in the escalation of sectarian violence in Iraq, particularly in Baghdad. Besides the newly elected Iraqi government, none of the emerging power structures had a localised territory or a compound. That soon changed with a rapid increase in the wave of ethnic cleansing between Sunni, Shiite and other mixed neighbourhoods that began in 2006 (Figure 9). Sadr city had a prominent role in this event, assisted by Jaish Al-Mahdi (Al-Mahdi army) and other Shiite militias supported by Iran, while Al-Qaeda in Iraq played a major role in assisting the Sunni insurgency inside and outside Baghdad.

Displacement has been one of the most pressing issues that the then newly formed Iraqi government originally led by PM Nouri Al-Maliki has had to deal with for nearly a decade. The International Organization for Migration estimates that in 2008 over 5 million Iraqis had been displaced internally and to neighbouring states amid brutal threats and housing evictions (Ladek, 2008). This equates to the displacement of one in five Iraqis. The figures are now much higher following the latest offences by the so-called Islamic State, Ba'ath loyalists and the Naqshbendi army, among others. A culture of squatting has emerged in the Iraqi social structure, and thousands of people in Baghdad have occupied abandoned houses, government buildings, schools and other public buildings awaiting the fate of authoritarian or militia eviction. Authority with different allegiances is imposed by both state power structures and anti-structures.

Toby Dodge (2013) describes the rise of a new authoritarianism in the Maliki regime that has threatened Iraq's democracy, exposing the network of a 'shadow state' that the now ousted Iraqi Prime Minister built in the years following 2006 as he states,

Maliki slowly built a shadow state that circumvented both the existing governing elite and democratic oversight of the exercise of power. It placed the Office of the Prime Minister at the centre of state power, reducing the ability of the cabinet and parliament to influence the formation and application of policy. (p. 245)

Al-Maliki has ironically employed similar tactics to those used by Saddam Hussein to increase control of state power, such as assigning significant roles to members of his family and others who have allied themselves to him. His son Ahmed Al-Maliki assumed a major role across all of Iraq's security services and his father's personal security. In addition to his main party, 'Dawa' the prime minister built a group of functionaries 'Malikiyoun' who had strong ties to him (Parker, 2012). Zaid Al-Ali (2014), a senior adviser on constitution building for International IDEA, discusses the 'ravages of corruption', which he refers to as 'the second insurgency' (p. 189) that has left Iraqis with little faith in their emerging democracy. That feeling has extended to Al-Maliki's government and to some extent (despite some improvement) to the current Iraqi government led by Prime Minister Haider Al-Abadi, as they often turn to militias for protection for a hefty price tag. Al-Ali gives an extensive account of the roots of corruption in the Iraqi government before and after the 2003 invasion. Much of this corruption can be traced back to Saddam Hussein's oppressive regime coupled with long years of sanctions (before 2003) followed by the breakdown in security and the criminal justice system (after 2003). This paved the way for officials to act in a context of 'impunity; targeted assassinations of state officials and random violence; [...] and gaps in the legal and 
institutional framework that was supposed to provide a check on government', as well as rivalry between government officials from different parties (Al-Ali, 2014: 189). Thus, social relationships became irreversibly fragmented, and Baghdad therefore reached a state of permanent and pure liminality, making it a fertile ground for creative, and sadly, destructive communitas.

\section{Territorial mapping | 5: Connectivity and the emergence of social nodes}

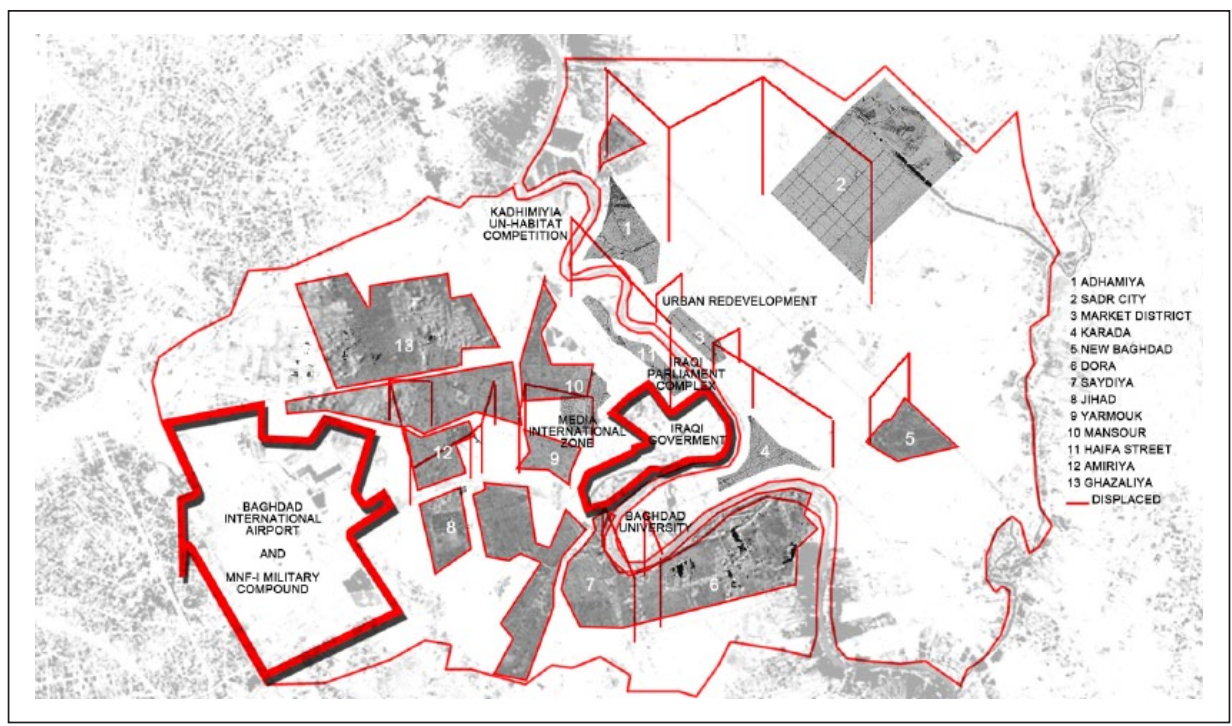

Figure 10. Displacement.

During the last 13 years of Saddam Hussein's regime (between 1990-2003), Iraq was denied connection to the rest of the world both physically and virtually. Baghdad Airport was abandoned with no flights arriving or departing, and Iraqis had no access to the Internet due to the regime's apparent fear of transparency. ${ }^{18}$ Just after the war broke out, Internet access increased and a wave of virtual expression came about in the form of documentaries, blogs, photographs and so on. The Internet witnessed a flood of unprecedentedly graphic images and footage of the war and its aftermath which continues until this day, examples of which can be seen in 'Alive in Baghdad, the Musings on Iraq' blog by Joel Wing, ${ }^{19}$ and Institute for the Study of War, among others. Being connected to and part of a larger virtual network gave people inside Iraq a glimpse of hope and further altered their perceptions of their embedded locatedness within this world. More importantly, it gave them a sense of freedom of speech. At last, there was a platform where people in Baghdad could talk freely about the abysmal situation that they were living in without fear of being imprisoned or persecuted. This era saw a surge in social nodes emerging on the web, most notably blogs such as: 'Where is Raed?' by Salam Pax ${ }^{20}$ and 'Baghdad Burning' by River Bend. ${ }^{21}$

The broken networks of displaced Iraqis (Figure 10) coupled with the emerging networks of power structures have acted as a spectacle for media attention. Twitter 
accounts of journalists on the ground have been disseminating streaming footage, breaking news and stories of suffering and hardship all across Iraq. In addition, fully funded grants have been awarded by the Iraqi government to Iraqi academics who wish to pursue doctoral degrees in Europe and the United States. Equally, there has been a surge of funding for urban regeneration. Architects and planners from all over the world have been invited to participate in competitions, conferences and talks. ${ }^{22}$ Such virtual social products of communitas are defined by their connectivity to physical social structures. They provide an alternative to existing social structures, emphasising the emergence of phenomena that depict Soja's idea of thirdspace. Turner (1974) elaborates on the relativity and the connectivity between communitas and social structure as being in a relationship of 'figure-ground', 'defined by contrast and comparison with the other' meanwhile both are governed by situational relationships that change in time (pp. 81-82).

\section{Conclusion}

Derek Gregory (2008) spoke of the biopolitics of Baghdad and described the way in which the perception of the city, from the point of view of the American troops, had to change from one of visualised three-dimensional buildings and maps of the city that are emptied of any human existence, to the reality of the on-ground situation. The enemy is no longer represented through 'prevailing models of urban warfare' treated 'as targets and as object-space - three-dimensional geometries of buildings, streets and utility networks - emptied of their population'. Instead, 'the military occupation evidently required different ways of comprehending the city' (Gregory, 2008: 6).

One the one hand, the biopolitics of Western powers played a big role in defining Baghdad's social and political landscape and urban context, but on the other hand, the Iraqi government (under Al-Maliki and now Al-Abadi) has had a much more defining impact on the deterioration of the social structures of the entire country over the last decade or so. It has driven the country into a liminal war state defined by necropolitics (Mbembe, 2003) where government elites are only concerned with amassing power and wealth while leaving their people to govern themselves. The multiple IS offences on northern and western Iraqi cities and the displacement and the massacres of the Yazidis among others who were abandoned by the government demonstrate this necropolitical condition of the current war state (Gržinić, 2012). Despite its effort to prove otherwise, as in early 2015, when it announced the abolition of the night-time curfew imposed on Baghdad by the United States in 2003, and subsequently the beginning of the dismantling of the blast walls in an attempt to instil the idea of normalisation of life among Iraqis and the Western media (Sly, 2015), Iraqis still do not have faith in their government. Moreover, Baghdad was at the time (February 2003), and still is, an open battlefield - an open system of pure liminality that has become a rite of passage, a highly complex multilayered network of mercenaries, contractors, insurgents, militia, gangs and a corrupt government, where money and power over territorial control plays a great part in defining the social and power structures within the city.

The connections I have established between the theoretical frameworks of Victor Turner's social anti-structures and Edward Soja's spatial reading of the city and thirdspace, the space of otherness represent the contribution I wish to make to the fields of 
critical urban theory and spatial politics in this article. I have extended Turner's liminality of the rite of passage into the current spatial and social conditions in Baghdad, emphasising the potential of the walling strategy as a generator of social and spatial structures and anti-structures that subvert the city. Furthermore, I have highlighted the interchangeability between the impact of the emerging social constructs and communitas on the city's spatial and territorial planning, and the effect of the liminal spatial configuration and segregation of the urban context on societal change. The use of territorial mappings as an illustration of a continual, liminal, and ephemeral process has been employed as a tool to expose one liminal network. The revealed network has extended Lefebvre's definition of space as a 'social product' (Lefebvre, 1991) and David Harvey's assertion that 'space is political' (Harvey, 2004) to establish that social urban space, in fact above all, is liminal. The material yet ephemeral presence of the concrete blast walls that have configured Baghdad's urban context has stimulated the emergence of social communitas and anti-structures, and, in turn, urban spaces have become generators for social structures and social change.

\section{Funding}

The author(s) received no financial support for the research, authorship, and/or publication of this article.

\section{Notes}

1. In his book, The Struggle for Iraq's Future, Zaid Al-Ali provides an extensive account of the legacy of oppression and violence in Iraq that has driven a wedge between the state powers and the Iraqi people since the proclamation of the state of Iraq (Al-Ali, 2014).

2. The subject of the relationship between 'civilians, conscript and career soldiering' merits study, in itself. Iraqi men have always been carted into the army whenever needed during the 45 years of Saddam Hussein's regime. They never felt that they had a choice in this matter, and they hated that; hence, men in particular were very much interested in leaving the country whenever opportunity arose.

3. Muqtada is one of the Al-Sadr family, the most influential religious Muslim Shiite family in Iraq. Allegedly, during Saddam Hussein's rule, Muqtada's father Mohammed Al-Sadr and two of his other sons were assassinated by the regime. Since then, Muqtada stepped in and took on his father's role as the symbolic leader of the Shiites in Iraq.

4. The Abbasid era began in the year $750 \mathrm{AD}$ with the establishment of the Abbasid Caliphate, the third of the Islamic caliphates to succeed the prophet Muhammad. The caliphate made Baghdad its capital, and during this era, the city enjoyed a period of cultural development, ending when the Caliphate was defeated by the Mongols in 1258.

5. Sadly, none of the original walls have survived. The four main gates, although not in their old glory, still mark more or less the main directions into south, north, east and west of the city. But only Baghdadis know this, and there is nothing more than an ordinary highway sign-like archway remaining in these locations. However, I would argue that, for Baghdadis, this residual sense of residing in a historically and ancient walled city would inflect how they would relate, consciously or subconsciously, to walled structures in their current urban environment.

6. UN Security Council Resolution 661 is thought to prescribe the harshest international economic sanctions imposed on a nation in the late 20th-century (Gordon, 2010: 20).

7. In the same UN Security Council Resolution (1483), there came a formal announcement of the end of the sanctions against Iraq (Gordon, 2010: 183). 
8. The Green Zone (currently known as the International Zone) refers to the secure area in central Baghdad where central government operates. The Red Zone refers to all areas in Baghdad that lie outside the Green Zone (Houghton and McDonald, 2006).

9. Blast walls were originally introduced as a temporary measure to protect public buildings and neighbourhoods, and to obstruct insurgent movements.

10. The wall between Israel and Palestine has provided the most informative precedent for the direction of my research. While this structure differs from the Baghdad walls in terms of spatial permanence (though studies on the temporality within its permanence have been put forward (Weizman, 2007)) and the nature of the resulting social divide, studies have confirmed the emergence of new types of mobility and social interference in and around this urban structure generated by segregation and conflict (Pullan, 2013; Weizman, 2007). Weizman describes the way a new urban syntax has been created within the conflict spaces of the West Bank by the military tactics of the Israeli army and Palestinian fighters alike. Both sides have altered the geometry of the urban battleground beyond the existence of the wall. The Israeli forces pierced holes in walls, ceilings and floors of inhabited buildings, and Palestinians exploited the topography by digging tunnels. In each case new paths were created that ran parallel to the public grain of the urban context. Weizman (2007) makes use of the critical theory of Deleuze and Guattari, Derrida and others to enrich his analysis of the West Bank and in so doing extends this theoretical context by making it applicable to current urban situations.

11. To Homi Bhabha (1994), the unsettling origin of the word territory, which is derived from the Latin words terra (meaning earth) and terrere (meaning to frighten), only confirms its negative connotations (p. 99).

12. Gennep spoke of three separate but successive stages to human rituals: separation, margin and aggregation.

13. Originally, a theoretical concept put forward by Michel Foucault (Foucault, 1997) that has been interpreted as either the proposition that biological life is the determining force of politics or that the core of the object of politics is life itself. Foucault later addressed this inconsistency by clarifying the definition of the term as encompassing both interpretations. Thomas Lemke et al. (2011) explains the way in which Foucault overcomes the two opposing views by combining both and asserting that life presents a border to politics that is both 'natural and given' as well as 'artificial and transformable' (pp. 4-5).

14. A concept initiated by Mbembe to indicate the strategic subjugation of life to the power of death (Mbembe, 2003).

15. Photographs taken by Kai Wiedenhöfer, an international award-winning photographer specialising in the subject of conflict and social tension in and around borders and blast walls. Permission for all five photographs has been granted by the photographer for this publication.

16. Saddam Hussein's regime took advantage of strategic sites in dense neighbourhoods to hide weapons and ammunitions. This resulted in endangering civilians living nearby and eventually leading civilians to flee their property.

17. Genius loci, or the protective spirit of a place, is a term borrowed from Roman Theology and further explored in architectural theory, by theorist Christian Norberg-Schulz (1980), due to its philosophical connection to place-making (Norberg-Schulz, 1980).

18. Iraqis were denied access to the Internet up until the end of 2003 invasion. Before that they had incredibly limited access (not to Google) but only to a server for e-mails that were regulated by the watchful eye of Saddam Hussein's regime. Also, Iraqis were not allowed to travel outside the country unless were sent by the government on a particular mission/visit. This restriction was implemented in 1990 after the gulf war.

19. http://musingsoniraq.blogspot.com/

20. http://dear_raed.blogspot.co.uk/ 
21. http://riverbendblog.blogspot.co.uk/

22. Author's conversations with architect Peter Besley of Assemblage, the winner of several competitions, including the Iraqi Parliament Complex and the UN-Habitat Housing Scheme, and Dr. Caecilia Pieri, an urban historian and Head of the Urban Observatory in the French Institute of the Near East, who has participated in conferences organised by the School of Architecture at Baghdad University, among others.

\section{References}

Al-Ali Z (2014) The Struggle for Iraq's Future: How Corruption, Incompetence and Sectarianism Have Undermined Democracy. New Haven, CT; London: Yale University Press.

Al-Hasani M (2012) Urban space transformation in old city of Baghdad: integration and management. Megaron 7(1): 79-90.

Anderson JL (2004) The Fall of Baghdad. New York: Penguin Press.

Bhabha H (1994) The Location of Culture. London: Routledge.

Boulton J (2014) Frontier wars: violence and space in Belfast, Northern Ireland. Totem: The University of Western Ontario Journal of Anthropology 22(1): 101-110.

Damluji M (2010) Securing democracy in Iraq. Traditional Dwellings and Settlements Review 21(2): 71-87.

Dobbins J, Jones S, Runkle B, et al. (2009) Occupying Iraq: A History of the Coalition Provisional Authority. Santa Monica: CA: National Security Research Division, RAND Corporation. Available at: http://www.rand.org/content/dam/rand/pubs/monographs/2009/RAND_ MG847.pdf (accessed 15 July 2015).

Dodge T (2013) State and society in Iraq ten years after regime change: the rise of a new authoritarianism. International Affairs 89(2): 241-257.

Dodge T (2014) Seeking to explain the rise of sectarianism in the Middle East: the case study of Iraq. Iraq between Maliki and the Islamic State, project on Middle East political science briefings 24. Available at: http://pomeps.org/2014/03/19/seeking-to-explain-the-rise-of-sectarianism-in-the-middle-east-the-case-study-of-iraq/ (accessed 15 July 2015).

Farrell S (2008) In Kurdistan, brisk business in blast walls (At war: notes from the front lines). The New York Times. Available at: http://atwar.blogs.nytimes.com/2008/03/11/in-kurdistanbrisk-business-in-blast-walls/?_php=true\&_type=blogs\&_r=0 (accessed 27 June 2014).

Finoki B (2009) Baghdad's post-blast wall Bibliothèque. In: Subtopia: a field guide to military urbanism. Available at: http://subtopia.blogspot.co.uk/2009/01/baghdads-post-blast-wallbibliothque.html (accessed 7 May 2014).

Foucault M (1997) The birth of biopolitics. In: Rabinow P (ed.) Michel Foucault, Ethics: Subjectivity and Truth. New York: The New Press, 73-79.

Gordon J (2010) Invisible War: The United States and the Iraq Sanctions. Cambridge, MA: Harvard University Press.

Gregory D (2008) The biopolitics of Baghdad: counterinsurgency and the counter-city. Human Geography 1(1): 6-27.

Gržinić M (2012) Biopolitics and Necropolitics in relation to the Lacanian four discourses. In: Proceedings of the symposium art and research: shared methodologies - politics and translation, Barcelona. Available at: http://www.ub.edu/doctorat_eapa/wp-content/uploads/2012/09/ Marina.Grzinic_Biopolitics-Necropolitics_Simposio_2012.pdf (accessed 21 May 2015).

Harvey D (2004) Space as a key word. In: Proceedings of the Marx and philosophy conference, Institute of Education, London. Available at: http://www.inter-accions.org/sites/default/files/ space-as-key-word-david-harvey.pdf (accessed 3 March 2014). 
Houghton RH and McDonald PJ (2006) A visitor's guide to Baghdad's international zone. Available at: http://bi.gazeta.pl/im/4/4646/m4646484.pdf (accessed 7 January 2014).

Ibhais H and Ayed K (2013) Am I Not Human? The Separation Wall in the West Bank. Beirut, Lebanon: Al-Zaytouna Centre for Studies and Consultations.

Johnson P (2006) Unravelling Foucault's 'different spaces'. History of the Human Sciences 19(4): 75-90.

Kilcullen D (2007) The urban tourniquet: 'gated communities' in Baghdad. In: Small wars journal blog. Available at: http://smallwarsjournal.com/blog/the-urban-tourniquet-gated-communities-in-baghdad (accessed 27 June 2014).

Kitchin R and Dodge M (2007) Rethinking maps. Progress in Human Geography 31(3): 1-14.

Klein N (2007) Disaster capitalism: the new economy of catastrophe. Harper's Magazine, October, 47-58.

Ladek DG (2008) Five Years on, More People Displaced than Ever before. The International Organization for Migration. Available at: https:/www.iom.int/news/five-years-more-peopledisplaced-ever (accessed 28 June 2014).

Lahoud A (2010) Post-Traumatic urbanism. Architectural Design 80(5): 14-23.

Lefebvre H (1991) The Production of Space. Oxford: Blackwell Publishing.

Lemke T, Casper M and Moore L (2011) Biopolitics: An Advanced Introduction. New York: New York University Press.

Lewis J (2014) ISIS battle plan for Baghdad: the Institute for the Study of War (ISW). Available at: http://www.understandingwar.org/sites/default/files/ISIS-not-culminated.pdf (accessed 30 June 2014).

Mbembe A (2003) Necropolitics (trans. L Meintjes). Public Culture 15(1): 11-40.

NGO Coordination Committee for Iraq (2010) Baghdad governorate profile, 2010. Available at: http://www.ncciraq.org/images/infobygov/NCCI_Baghdad_Governorate_Profile.pdf (accessed 7 January 2014).

Norberg-Schulz C (1980) Genius Loci: Towards a Phenomenology of Architecture. New York: Rizzoli International Publications.

Parker N (2012) The Iraq we left behind; welcome to the world's next failed state. International Affairs 91(2): 94-110.

Peterson A (2002) Dictionary of Islamic Architecture. Abingdon: Taylor \& Francis.

Pieri C (2014) Can T-wall murals really beautify the fragmented Baghdad? Jadaliyya. Available at: http://www.jadaliyya.com/pages/index/17704/can-t-wall-murals-really-beautify-the-fragmented-b (accessed 21 May 2014).

Pullan W (2013) Conflict's tools: borders, boundaries and mobility in Jerusalem's spatial structures. Mobilities 8(1): 125-147.

Salem P (1994) Bitter Legacy: Ideology and Politics in the Arab World. Syracuse, NY: Syracuse University Press.

Sly L (2015) As a curfew is lifted, Baghdad is at long last partying again. The Washington Post. Available at: http://www.washingtonpost.com/world/middle_east/baghdad-will-soon-beable-to-party-past-midnight-as-curfew-is-lifted/2015/02/05/fe1dd98e-ad3d-11e4-abe8-e1ef60ca26de_story.html (accessed 21 May 2015).

Soja E (1996) Thirdspace. Malden, MA: Blackwell Publishing.

Thomassen B (2009) The uses and meanings of liminality. International Political Anthropology 2(1): 5-28.

Turner V (1964) Betwixt and between: the liminal period in Rites de passage. In: Proceedings of the 1964 Annual Spring Meeting of the American Ethnological Society, symposium on new approaches to the study of religion. Seattle, WA: Washington Press, 4-20. 
Turner V (1974) Liminal to liminoid, in play, flow, and ritual: an essay in comparative symbology. Rice University Studies 60(3): 53-92.

Weizman E (2003) The politics of verticality: the West Bank as an architectural construction. In: Franke A (ed.) Territories: Islands, Camps, and other States of Utopia. Berlin: KW - Institute for Contemporary Art, 65-118.

Weizman E (2007) Hollow Land: Israel's Architecture of Occupation. London: Verso.

\section{Author biography}

Sana Murrani is an experimental architect and theorist in spatial practice, and currently holds the position of Lecturer in Architecture at Plymouth University, United Kingdom. She studied architecture at Baghdad University School of Architecture at both under-graduate and post-graduate level. Dr. Murrani is a member of the Planetary Collegium's CAiiA-Hub in Plymouth, United Kingdom, where she undertook her $\mathrm{PhD}$ on the subject of theoretical encounters and the critique of architectural representation and material culture under the influence of technology. Her principal research interest is in the field of liminal spatial and social practice with a particular focus on the transient conditions of Worldmaking. Her work focuses on linking contemporary spatial philosophy and current critical theories of social practice influenced by technoscience in order to reveal the conditions of the marginalised, the contested and the peripheral in any inhabited situation/urban context, using inter/trans-disciplinary methodologies such as second-order cybernetics, transmedia representation tools/mapping and digital anthropology. She has published in peerreviewed journals and participated in international conferences and workshops and is currently a reviewer for Leonardo Reviews: The International Society for the Arts, Sciences, and Technology and Routledge Architecture Thinkers for Architects series. 